\title{
Brand Cities under the Effect of Consumption Society
}

\author{
Ahsen Sacli \\ Abant İzzet Baysal University, Faculty of Economics and Administrative Sciences, \\ Department of Public Administration, Bolu, Turkey \\ E-posta: ahsen1tr@gmail.com
}

\begin{abstract}
Every kind of material including service sector which can be advertised and branded can be a subject to the consumption activity of consumption society. In the new consumption model, everything which provides more fun, enjoyment and happiness is always chosen more. The cities in which people inhabit are included in this phenomenon besides needed materials. Now, inhabitability of the cities has become more important than ever. In this way, with globalization, borders have lost their importance in the world formed according to the conditions of the consumption society and a competition among cities which attract more tourists, more industrialists and investors, and more students has come in sight. When it comes to a competition, image making and branding works have become significant for the cities as well. While efforts to create a city identity have brought cultural assets into the forefront, in some cities, natural assets have featured thanks to those efforts. Some cities have gained their identity through their industrial foundations while others have taken their identity with education institutions.

Creating a city identity and making the city a brand has almost become an obligation in today's world. Origins of cities' branding which has become so important are based on branding of the products which have become a classic. Because the most important point in branding is the image case, the cities which are labelled with terror or various crimes must change this image in order to become a brand city so that they can be more inhabitable, and people can travel, work and get education. The consumption society that has been created by today's economic system requires that one. Apart from the cities which are well-known worldwide such as Paris, Las Vegas, Venice, standing out as an important center for trade, a product or service, various activities such as conferences and exhibitions or sport activities such as Olympiads has become very significant. Of course, cities are not products and state are not producers. Hence, inhabitants of the cities are not consumers in common meaning. The most important difficulties which lie in the way of creating a brand city come into existence at this point. Firstly, because a way in which as if a product was marketed should be followed, determining a framework appropriate for national policies, especially economic difficulties is also significant.

This study depends on a literature review. In this study, historical process of consumption society that has been created with globalization will be briefly examined. Afterwards, the effects of consumption society on branding of the cities and creation of brand cities will be discussed.
\end{abstract}

Keywords: Globalization, Consumption Society, Brand, Brand Cities

DOI: $10.7176 / \mathrm{JSTR} / 5-3-17$

\section{Tüketim Toplumunun Etkisinde Marka Kentler}

\section{Özet}

Tüketim toplumunun tüketme eylemine, reklamı yapılabilen, markalaştırılabilen, hizmet sektörü dahil her türlü materyal konu olabilmektedir. Yeni tüketim sisteminde her zaman, daha fazla eğlence, daha fazla zevk veren ve daha fazla mutlu eden her şey daha fazla tercih edilmektedir. Bu duruma ihtiyaç malzemeleri kadar yaşanılan kentler de dâhildir. Artık kentlerin yaşanabilirliği çok daha fazla önem arz etmektedir. Böylece küreselleşmeyle birlikte, tüketim toplumu şartlarına göre oluşan dünyada sınırların önemi kalmamış, daha fazla turist, daha fazla sanayici ve yatırımcı, daha fazla öğrenciyi çeken kentler arası rekabet ortaya çıkmıştır. Rekabet söz konusu olunca doğal olarak, imaj yaratma ve markalaşma çalışmaları kentler için de geçerli hale gelmiştir. Bir kent kimliği oluşturma çabaları, kentin sembolü olarak bazı kentlerde kültür varlıklarını öne çıkarırken bazı kentler de doğal varlıkları ön plana çıkarmaktadır. Bazı kentler sanayi kuruluşları, bazıları da eğitim-öğretim kurumları ile kimlik 


\section{kazanmaktadır.}

Kent kimliği oluşturmak, kenti marka haline getirmek günümüzde neredeyse zorunlu hale gelmiştir. Bu kadar önemli hale gelen kentlerin markalaşmasının kökenleri, ürünlerin klasikleşen markalaşmasına dayanmaktadır. Markalaşmanın en önemli noktası imaj konusu olduğundan, örneğin, terör veya çeşitli suçlarla tanınan kentler markalaşmak için önce bu imajlarını değiş̧irmek zorundadırlar ki daha yaşanılabilir, seyahat edilebilir, çalışılabilir ya da öğrenim görülebilir olsunlar. Günümüzün ekonomik sisteminin yarattığ1 tüketim toplumu bunu gerektirmektedir. Paris, Las Vegas, Venedik gibi dünyaca tanınan kentlerin haricinde, ticaret merkezi olmak, herhangi bir ürün ya da hizmetin merkezi olmak, konferans, sergi gibi çeşitli etkinlikler için veya olimpiyatlar gibi spor etkinlikleri için ön plana çıkmak önemli hale gelmiştir. Tabii ki kentler bir ürün değil, devletler de üretici değildir. Dolayısıyla kentte yaşayanlar da bilinen anlamıyla tüketici değildir. Marka kent yaratmanın önündeki en önemli zorluklar da burada ortaya çıkmaktadır. Her şeyden önce tıpkı bir ürün pazarlanıyormuş gibi bir yol izlenmesi gerektiğinden, mali zorunluluklar başta olmak üzere ulusal politikalara uygun bir çerçeve belirlemek de önem arz etmektedir.

Çalışma literatür taramasına dayanacaktır. Bu çalışmada küreselleşme ile birlikte oluşan tüketim toplumunun tarihsel gelişimi kısaca irdelenecektir. Daha sonra tüketim toplumunun, kentlerin markalaşmasının üzerine olan etkileri ile marka kentlerin oluşumu incelenecektir.

\section{Anahtar Kelimeler: Küreselleşme, Tüketim Toplumu, Marka, Marka Kentler}

\section{GÍRISS}

1990'lı yıllardan bu yana dünyanın gündeminde olan küreselleşme olgusu büyük değişimlere neden olmuştur. Geçmişten günümüze yaşanan bu süreçte, sosyo-kültürel, ekonomik ve siyasal alanlarda ortaya çıkan ve devam eden dönüşümler doğal olarak toplumsal yapıları ve bireylerin gündelik yaşamını da etkilemektedir. $\mathrm{Bu}$ dönüşümlerin başlangıç noktası için endüstri devrimine kadar gitmek mümkünse de, 19. yüzyılda kullanılmaya başlanan seri üretim tarzının giderek ekonomik sistemlere hâkim olmasıyla başlamıştır denilebilir. Seri üretim tarzı sonucunda ortaya çıkan ve değişerek büyüyen tüketim tarzı da tüketim toplumunu gündeme getirmiştir.

20. yüzyılın ilk yıllarında başlayan büyük miktarlarda toplu üretim ve tüketim modelinin yaygınlaşması, tüm toplumsal parametreleri çalışmak, üretmek ve tüketmek olan sanayi toplumunu yaratmıștır. Birçok bilim insanının vurguladığı gibi geçmiş medeniyetlerde üretilen bina, araç ve tüm diğer ihtiyaç malzemeleri dayanıklı materyaller olarak üretildiği için, tüketim de ona göre şekillenmiştir. Dolayısıyla toplum modeli de üretici ve tasarrufçu olarak biçimlenmiştir. Bilim ve teknolojideki ilerlemelerle birlikte sermayenin emekten bağımsızlaştırılması sonucunda oluşan toplumsal modelde üretimden çok tüketimin önemli hale gelmesi de 21. yüzyılın tüketim toplumunu oluşturmuştur. Ortaya çıkan bu toplum modelinde tüketimi özendirecek tüm materyaller önem kazanmıştır. Tüketimi artırmak için herhangi bir ürünün üretilmesinde özellikle, üretim modelinden başlayarak, ürünün malzemesinden, tüketime sunulmasına, marka ve reklam çalışmalarına, atıkların nasıl değerlendirileceğine kadar her aşamada ürünü tüketici için cazip hale getirecek birçok adımı içeren bir süreç söz konusudur.

21. yüzyılda, bilim ve teknolojide inanılmaz bir hıza ulaşan gelişmelerle özelikle iletişim teknolojilerinde sağlanan ilerleme dünyanın ekonomik sistemini neredeyse "bir" hale getirmiştir. Bu yüzyılda ekonomik büyüme, ticaretin gelişmesi, eğitim düzeyinin artması, bebek ölüm oranlarının düşmesi, insan ömrünün uzaması, dolayısıyla dünya nüfusunun artması, kentleşmenin artması, sosyal ve siyasal hayatın değiş̧mesi, teknolojinin değişim hızına yakın bir hızda gerçekleşmektedir. Tüm bunların sonucunda doğal olarak uluslararası ilişkilerde de dikkat çekici değişimler yaşanmaktadır. Örneğin bazı kentler uluslararası ticaret alanında, bazı kentler turizm alanında, bazıları da eğitim alanında ya da daha farklı alanlarda bağlı bulundukları devletlerden daha fazla ön plana çıkmaktadır. Küreselleşme sürecinin ortaya çıkardığı bu durum uluslararası politikada kentlerin konumunu da etkilemiş, ekonomik ve politik anlamda yerelleşmenin önem kazanmasını sağlamıştır. Gelinen noktada özetle, ulus devlet yapısını aşan kentler ortaya çıkmış ve bu kentlerin arasında da önemli oranda rekabet ortamı oluşmuştur.

Paris Eiffel Kulesi, Roma tarihi ve dini mekânları, Las Vegas kumarhaneleri ile tanınmışlardır. Aynı zamanda Paris ve Venedik âşıklar şehri olarak tanınmaktadırlar. New York dünyanın ticaret merkezlerinden biri olarak, Los Angeles Hollywood'la dünyanın sinema sektörünün merkezi olarak, San Francisco Silikon vadisi ile bilişim sektörünün en önemli merkezi olarak tanınmaktadır. Bu ve bunun gibi kentler marka olmak için herhangi bir çaba sarf etmemişlerdir. Ancak diğer kentler küresel sisteme dâhil olmak ve küresel sermayeden biraz daha fazla pay alabilmek için rekabet etmek amacıyla kentlerinin bilinirliğini artırmak durumundadırlar. Bilinirliğini artırmanın yollarından biri de kentin marka olmasıdır. Bir kentin marka kent olması için hâlihazırda belirlenmiş bir yol haritası olmasa da, herhangi bir ürünün markalaşması için izlenen yolun kentlere uyarlanmış hali ile birlikte marka kentlerin edinilmiş tecrübelerinden yararlanılarak yola çıkılmaktadır. Zaten kentlerin her biri coğrafi, idari, mali durum gibi her açıdan farklılık arz ettiği için de tek bir yol belirlenmesi mümkün değildir. Sonuç olarak marka kent olmanın ana hatlarıyla belirlenmiş olan yolunu takip ederek, her kent kendine özgü şartlarıyla marka olabilir. 
$\mathrm{Bu}$ çalışmada tüketim toplumu ve ortaya çıkış süreci üzerinde kısaca durulduktan sonra kent kavramına değinilecektir. Ayrıca tüketim toplumu nedeniyle kentlerde meydana gelen değişimler ile marka kavramı ve marka kentler konusu anlatılarak, tüketim toplumunun kentlerin marka olma çabalarındaki etkisi tartışılacaktır.

\section{TÜKETIM TOPLUMUNUN KISA TARIHI}

\subsection{Tüketim ve Tüketim Toplumu Kavramı}

Tüketim, insanlık tarihi boyunca doğal olarak var olan bir eylemdir. Türk Dil Kurumu Sözlüğünde tüketim, üretilen veya yapılan şeylerin kullanılıp harcanması olarak tanımlanmaktadır. Tüketim toplumunu, “...tüm tüketim faaliyetlerinin fiyat-değişim ilişkisi içerisinde, belirli pazar ilişkileri dâhilinde gerçekleştiği bir yapt...” olarak açıklayan Uğur Batı'ya göre tüketim toplumu, tüketicinin, tüketim ideolojisi tarafindan yönlendirildiği bir toplum modelidir (Bat1 3, 2018:35).

Jean Baudrillard'a göre ise, tüketim bir efsanedir. Günümüz toplumlarının kendisi hakkında söylediği bir söz, kendisiyle konuşma tarzıdır. Tüketim toplumlarının tek nesnel gerçekliği tüketim fikridir. Günümüz toplumu, kendini tüketim toplumu olarak düşünür ve öyle olduğunu konuşur. Bu toplum tükettiği ölçüde kendini tüketim toplumu olarak, fikirde tüketir. Reklam, bu fikrin zafer türküsüdür (Baudrillard, 2017:254). Dolayısıyla, tüketim toplumu 21. yüzyılın baskın toplum modeli olarak sunulmakla birlikte, aslında mevcut ekonomik sistem nedeniyle fikren üretilmiş bir toplum modeli olduğu da ileri sürülmektedir. Çünkü kapitalizm tüketimle vardır ve tüketim sürdükçe de var olmaya devam edecektir. Jean Baudrillard'a göre, "tüketim artık hiçbir anlama gelmediğinde herkese özgü bir şey haline gelecektir" (Baudrillard, 2017:63).

Günümüzde özellikle gelişmiş ülke toplumları açısından değerlendirildiğinde, aşırı tüketim gözle görülür düzeydedir ve tüketim toplumu üzerinde durulması gereken bir gerçekliktir.

\subsection{IIlkel Toplumdan Modern Topluma Geçiş: ${ }^{1}$}

İnsanlığın başlangıcını yaklaşık M.Ö. 50000'lere dayandıran bilim insanları uygarlığın da, M.Ö. 4000'lerde Yakın Doğu'da ilk kent merkezlerinin ortaya çıkmasıyla başladığını ileri sürmektedirler. İnsanın tarımı bulması ve yerleşik hayata geçmesiyle birlikte kentleşme, devlet yapısının kurulması, yazının bulunması, kanunların oluşturulması, matematik gibi bilimsel çalışmaların başlaması ve toplumsal örgütlenme yapılarının ilk örneklerinin görülmeye başlaması ile uygarlık başlamıştır. Ekonomik anlamda avcı-toplayıcılıktan yiyecek üretimine ve birikime başlayan insan, tarıma dayalı yaşam tarzının getirdiği artan ihtiyaçlarla birlikte gelişen teknoloji, beraberinde endüstri devrimini getirmiştir (McClellan III ve Dorn, 2006:5-9).

Ulus devletlerin ortaya çıkması, feodal yapının 11. yüzyıldan başlayarak ortadan kalkmasıyla gerçekleşmiştir. Toplumun dönüşümü, ekonomik yapının da dönüşümünü içine alan bir değerler sistemini anlatmaktadır. Bu değerler, toplumun dünya görüşü, bilim ve teknolojide geldiği nokta, siyasal ve ekonomik düzeni de belirleyen bir bütündür. Ortaçağın sonlarında yaşanan değerler değişimini hazırlayan faktörler, 10. - 15. yüzyıllar arasında yaşanan ticaretin gelişmesi ve ulus devletlerin de ticareti bir faaliyet alanı haline getirmesi ile 16. - 17. yüzyıllarda kapitalizmin doğması olmuştur. Kapitalizmin gelişmesiyle birlikte, Reformasyon'un da desteğini alan insan maddi kazançları için çalışması gerektiği inancına sahip olmuştur. Reformasyon'un getirdiği seküler dünya anlayışı maddi dünyanın gelişiminde önemli bir temel oluşturmuştur. Yine de endüstri devrimi öncesi toplum büyük oranda tarım toplumuydu. Makineleşme ve fabrika sistemleri çok yoğun olmadığından daha çok aile işletmeleriyle ilerleyen çalışma hayatı uzmanlaşmaya dayanmamaktaydı ve ihtiyaçlar da buna göre kısıtlıydı (Sander (I), 2005:100).

16. yüzyılın bilim insanlarından Bacon "bilgi kuvvettir" diyerek ilerleme fikrini öne sürmüştür. Descartes da Bacon gibi bilgi ile güç arasında bağlantı kurmuş, ilerleme fikrini desteklemiştir. Dolayısıyla 18. yüzyıl Aydınlanma yüzyılı olarak aklın öncelendiği, bilgi ve birey üzerine kurulu bir dünya düzeni yaratmıştır. Doğal olarak ardından gelen Endüstri devrimi de, 18. yüzyılın sonlarından itibaren ekonomik ve siyasal yapı dâhil her şeyi değiştirdiği gibi toplumsal yapıda da köklü değişimlere neden olmuştur. Toplumsal açıdan en fazla dikkat çeken değişimler, insan ömrünün uzaması ve bebek ölüm oranlarının düşmesi nedeniyle hızlı nüfus artışı, hızlı kentleşme ve yaşam standardının yükselmesidir. Ayrıca üretimin artması yeni pazarlar gerektirirken, sermayenin birikmesine ve yeni yatırım olanaklarının aranmasına neden olmuştur. Bu durum doğal olarak sınıf bilincinin de yerleşmesini sağlamıştır (Ünder, 1996:38). 19. yüzyılda geliştirilen montaj hattı ve değiştirilebilir parça üretimine geçilmesi, modern anlamda fabrikanın gelişimini çok hızlandırmıştır. Tüm bu gelişmeler hizmet sektörünü doğurmuş, birçok yeni meslek alanları ortaya çıkmış, kadınların iş hayatına yoğun katılımını sağlamıştır. Dolayısıyla endüstri devrimi ile endüstri toplumu doğmuştur. Diğer bir deyişle sanayi toplumu, bilime ve gelişmeye önem veren, rahat ve sağlıklı yaşamak isteyen, insan ömrünün uzadığı bir toplum olarak öne çıkmıştır. Sonuç olarak endüstri devrimi ile ilgili olarak toplumsal açıdan en dikkat çekici gelişme, tüketim toplumunun ilk

\footnotetext{
${ }^{1}$ Bu bölüm hazırlanırken ă̆ırlıklı olarak Ahsen Saçlı’nın "Uluslararası Çevre Politikaları Çerçevesinde Çevre-Teknoloji Illişkisi”" adlı yayınlanmamış Doktora Tezinden yararlanılmıştır.

150 | P a g e

www.iiste.org
} 
aşamalarının ortaya çıktığının görülmesidir. Bu arada da süreç içerisinde gelişmiş ülkeler ile diğerleri arasındaki farklar da giderek artmıştır.

2. Dünya Savaşı'nın sonrasında bilimsel ve teknolojik gelişmeler eskisine nazaran daha hızlı ilerlemiştir. Savaş sonrasında en fazla etkiyi toplumsal ve ekonomik hayat görmüştür. Teknolojik gelişmeler endüstriyel gelişmeleri de hızlandırdığ 1 için üretim daha da artmış, kitlesel üretim ortaya çıkmıştır. Çalışma hayatında işgücü, tarımdan endüstriye, oradan da bilgi ve enformasyon toplumunu oluşturan sektörlere kaymıştır. Teknolojinin gelişmesi çeșitliliği de beraberinde getirmiş, yeni iş alanları açılmış, ayrıca iş saatlerinin azaltılması gibi modern toplumun getirdiği yaşam kalitesi standartları sonucunda da teknolojik işsizlik de yaşanmamıştır (Habermas, 2002:104-117). Endüstriyel anlamda ilerlemiş toplumlar, normlar tarafından yönlendirilen değil, dış çekicilikleri nedeniyle bir davranış kontrolü modeline uydukları, teknolojik gelişmelerin yönünün ve hızının toplumların ilgileri tarafından belirlendiği toplumlardır (Habermas, 2004:54-55). 2. Dünya Savaşı sonrasında ortaya çıkan teknolojiye dayalı toplum modeli tüm dünyaya hâkim olmuştur. Bilimin sağladığı bilgi ve teknolojinin geliştirilmesinin beraberinde getirdiği kolaylıklar, daha fazla yiyecek ve giyecek maddesi sağlamış, uzaklar yakın olmuş, hastalıklar azalmıştır. Bilim ve teknolojinin toplumları şekillendirmede güçlü etkisi bulunmaktadır. Özellikle iletişim teknolojileri insan hayatının ayrılmaz bir parçası haline gelmiştir (Mayor ve Forti, 2004:5). Böylece ortaya çıkan bilgi toplumunda, ürün üretimi yerine bilginin üretimi öne çıkmış, bilginin değeri yükselmiştir. "Sanayi sonrası toplum" olarak da adlandırılan bilgi toplumunun dikkat çeken özelliği, mal üretiminden hizmet üretimine doğru yönlenmenin olmasıdır. Sanayi toplumunun ekonomik yapısı; mal üretimi için gerekli sermaye birikimi, iş bölümüne dayalı üretimde uzmanlaşma ile üretim ve tüketimin fabrika ve ev olarak ayrılmış birimlerde gerçekleştirilmesi şeklindedir. Bilgi toplumunun ekonomik yapısı ise; ürünler yerine bilgi üretilmekte ve bilgiyi kullanarak yapılan üretim öne çıkmaktadır. Bilgi teknolojilerine bağlı olarak üretilen bilgi artmakta ve bilginin birikimi sağlanmaktadır. Birikmiş bilginin üretime hız kazandıran etkisi ile bilgi üretimi ve bilgiden yararlanarak üretimin gerçekleştirilmesi daha da hızlanmaktadır. Özetle ekonomik yapı, endüstri toplumunun değişim ekonomisinden, bilgi toplumunun hızlı ekonomisine dönüşmüştür (Kutlu, 2000:182). Bu durum da tüketim toplumunun güçlü altyapısını hazırlamışıır.

\subsection{Tüketim Toplumuna Geçiş:}

Modern dönemden itibaren sosyal ve ekonomik yapılarda tüketim konusunun kuramsal analizini yapmak için kapitalizm temel niteliğindedir. Kapitalist toplumlar, pazarda değişim amacı ile tüketimin hâkim olduğu, tüketim toplumlarıdır. Kapitalizmin temelini metaların üretimini sınırsız boyuta vardıran kar olgusu olușturmaktadır. Kapitalizmi en çok eleştiren Marks'a göre tüketim malı, doğrudan kullanım ve tüketim amacı ile değil, pazarda satış amacı ile üretilen bir üründür. Bu durum, üretilen malların normal olarak tüketiciye satılıp kar elde edilmesi için değil, hemen tüketilmesi ya da kullanılması için üretildiği feodal tarz tarımsal üretimden farklıdır (Batı 1, 2015:32).

Kentleşme gibi, örgün eğitim gibi toplumsal yapıyı belirleyen faktörlerin önem kazanarak, toplumsal ilişkilerin geleneksel yapısından uzaklaştı̆̆ı, toplumdaki konum ve kişisel kimliğin tüketime göre belirlendiği modern toplumlarda, harcama dikkat çekici şekilde artmıştır. Kapitalist sistemde, üretilen metanın dağıtım, değiş-tokuş ve tüketim dolaşımına girerek karın sermayenin sahibine geri dönmesi zorunludur. Kapitalist sistemin sekteye uğramadan devam etmesi için bu döngünün sürmesi gerekmektedir. Kapitalizm için kitle üretimi sorunu söz konusu değildir. Sorun tüketimin artarak sürmesini sağlamaktadır (Jhally, 2002:78'den alıntı yapan Aydoğan, 2009:204).

Modern kapitalizmin ürünü olan tüketim malları, kar elde etmek amacıyla uluslararası pazarda satılmaktadır. Kapitalizmin sürekliliğinin sağlanması için gerekli unsur olan piyasa ve değişim değerini devamlı kılmanın yolu tüketimin bu unsurları desteklemesidir. Metanın sınırsız yayılmasını sağlayan faktörlerden biri, üretimin miktarına eş bir tüketim sağlamak için gerçek olmayan ihtiyaçları yaratmaktır. Kapitalist toplum yapısında üretilen malların yani metaların, onları üreten bireylerin arasındaki ilişkiyi belirlediği görülmektedir. Bu durum da metanın bir tür fetişist özellik gösterdiğinin kanıtıdır. Kapitalizmin yaratmak istediği hep daha fazla tüketim bağımlılığı ile meta fetişizmi arasında sıkı bir bağ vardır. Tüm bunların sonucunda tüketim toplumunda tüketimin kendisi bir ihtiyaç haline gelmiştir. Bireyler artık ihtiyaç duyduğu ya da gerekli olduğu için tüketmiyor, tüketmeye ihtiyaç duyuyor (Batı 1, 2015:33-34). Kapitalizmin gereği olduğu ileri sürülen tüketimin, toplumların abartılı bir şekilde kendinden zevk aldığı bir aynaya dönüştürülerek, toplumun kendisinin öncelediği modernliğin ahlakını oluşturduğu düşünülmektedir. Artık bir haz alma düzeyinde olan tüketim, toplumsal bilinçte de öncelenmektedir (Baudrillard, 2017:254). Tüketim kapitalizmi, aslında kendiliğinden güzel olan bir şeyi gereksiz yere süslemeye çalışmaktan başka bir şey değildir. Ancak haz halini alan tüketim, alınan gıdadan özel hayata kadar insan hayatına dair ne varsa prestij meselesi haline getirmektedir (Miller, 2012:369). Özetle kapitalist sistem, günümüzde dünyaya gelen her bir bireyi tüketici olarak kodlamaktadır. Buna göre, herkes doğuştan tüketici olma hakkına ve yetisine sahiptir. Kapitalizm bu durumu özgürlük ideolojisi olarak sunmaktadır. Tüketimin hedonik (hazcı) yapısı, onun sınırsız ve doyurulamaz bir ihtiyaçlar kümesi oluşturduğunun önemli göstergesidir (Batı 2, 2015:77).

$151 \mid \mathrm{P}$ a g e

www.iiste.org 
Dolayısıyla günümüz insanının psikolojisi üzerinde de etkili olan bu durum dünyanın tek geçerli sistemi haline gelmiştir ve toplum yapıları da buna göre şekillenmektedir.

\section{KENT VE TÜKETIM TOPLUMUNUN KENTLERİ}

\subsection{Kent ve Kentleşme Kavramları:}

Kentbilim Terimleri Sözlüğ̈̈nde kent, sürekli toplumsal gelişme içinde bulunan ve toplumun, yerleşme, barınma, gidişgeliş, çalışma, dinlenme, eğlenme gibi gereksinmelerinin karşılandığı, pek az kimsenin tarımsal uğraşılarda bulunduğu, köylere bakarak nüfus yönünden daha yoğun olan ve küçük komşuluk birimlerinden oluşan yerleşme birimi (Keleş, 1998:75), kentleşme ise, endüstrileşmeye ve ekonomik gelişmeye koşut olarak kent sayısının artması ve kentlerin büyümesi sonucunu doğuran, toplumda artan oranda örgütleşmeye, uzmanlaşmaya ve insanlararası ilişkilerde kentlere özgü değişikliklere yol açan nüfus birikim süreci olarak tanımlanmaktadır (Keleş, 1998:80).

Kent, bir yerleşim birimidir. Kentlerde bulunan nüfus ağırlıkla tarım dışı üretimle uğraşır. Toplumsal ilişkiler ve kültürel alanlar ön plandadır. Heterojen bir nüfus büyüklüğüne sahiptir. Nüfus yoğunluğu, sosyo-külttürel yapısı, ekonomik yapısı gibi birçok nedenle kırsal alanlardan farklı yerlerdir. Doğal olarak, ilk kentlerle günümüzün kentleri de birbirinden farklıdır. Özellikle Ortaçağ'da ekonomik ve politik açıdan kendi bölgelerini yöneterek özerkliğin en geniş formunu yaşamışlardır. Kapitalizmin gelişme sürecine uygun olarak ulus devletlerin ortaya çıkması ve ülkelerin merkezileştirilmeleri sonucunda kentler özerkliklerini kaybetmiş̧lerdir. Kentler ulusal ekonomilerin çizdiği çerçevede konumlanmış, ulusal pazara bağımlı hale gelmişlerdir. Günümüzün kentleri Endüstri Devriminin ürünüdür. İlk kentlerin gelişmesi ve değişmesi Endüstri Devrimine kadar oldukça yavaş ilerlemiştir. Sanayileşmenin ortaya çıkmasıyla birlikte hem toplumsal yapı hem de kentler hızlı bir dönüşüm sürecinin içine girmiştir. Bilim ve teknolojide yaşanan ilerlemeler sanayi toplumunun ardından bilgi toplumunu getirmiştir. Kentler de bu yeni şekillenen toplumun gereklerine göre değişim ve dönüşüm geçirmeye çok hızlı bir şekilde devam etmektedir (Kaypak, 2013:343). Özetle, zaman içinde gerçekleşen küreselleşmenin de etkisiyle günümüzün kentleri, gerek tanınılık gerekse diğer dünya kentleri ile rekabet açısından, gerekse de ticaret açısından, içinde bulundukları devletin zaman zaman önüne geçmektedirler.

\subsection{Tüketim Toplumunun Etkisinde Kentler:}

Tarımın bulunması, insanların toprağa yerleşmesini sağlamıştır. Bu da nüfusun belli yerlerde toplanmasının yolunu açmıştır. Böylelikle başlayan kentleşme tarihi, uygarlığın tarihi olmuştur. Modern dönemden önce kentler ekonomik anlamda el sanatlarının ve insan ya da hayvan enerjisiyle üretilen eşyaların satıldığı pazar veya mübadele yeri görünümündedir. Bu dönemde işbölümü ve uzmanlaşma çok az görülmekteydi. Toplum katı bir hiyerarşik düzene sahip olduğundan farklı grupların ya da zanaatkârların yerleşim yerleri ayrı ayrı şekilmekteydi. Bu dönemin kentleri uzmanlaşmanın olmadığı, evlerin aynı zamanda işyeri, ibadet yeri, alışveriş yeri, eğitim yeri olarak kullanıldığı görülmekteydi. Kentlerin büyümesi ise 16. yüzyılda başlar. Modern dönemin ilk zamanlarından itibaren ekonomik ve sosyal ilişkiler değişmeye başlamıştır. Büyüyen kentlerde sermaye sahipleri ile çalışan kesim arasındaki sınıfsal farklar modern dönemde belirginleşmeye başlamıştır. Yerleşim kanunu, eğitim kanunu, yoksulluk kanunu, kamu sağlığı kanunu gibi yasal düzenlemelerle birlikte gelenekler ve sosyo-kültürel hayat gibi toplumsal olan her şeyde yaşanan değişimler dâhil yeni yaşam şekilleri oluşmaya başlamıştır (Aydoğan, 2009:207). Bu yaşam şekillerinden en etkili olanı tüketmeye yönelik yaşam formudur. Böylece salt tüketimin öncelendiği ekonomik sistem, kendi tüketim toplumunu yaratmıştır.

Uğur Batı'ya göre, üretim ve üretimin tüm süreçlerinin toplumsal merkezdeki yerini tüketim olgusuna bırakmas1 ile tüketim kültürü ve tüketim toplumu varlık kazanmıştır. Tüketim artık insanların gündelik hayatının her alanında toplumsal yaşam ve kültürel değerlerde merkezi bir konuma yerleşmiş̧ir. Tüketimin ögeleri, arzu nesneleri artık insanlara sanal dünyada elle dokunulabilen, sahip olunabilen, gözle görülebilen mutluluklar satmaya başlamıştır (Batı 2, 2015:77). Günümüzde tüketim o hale gelmiştir ki George Ritzer göre, yeni tüketim araçları "tüketim katedralleri” olarak nitelendirilmektedir. Tüketim katedralleri büyülü hatta kutsal bir karakter sahibi olarak yapılandırılmaktadır. Tüketiciyi kendilerine çekmek için büyülü bir ortam sunmaları tesadüf değildir. Burada amaç insanları tüketim tapınağında tapınmaya çekmektir. Kaldı ki sundukları fantastik, kutsal ortamda da oldukça başarılı olmaktadırlar. Örneğin Disney Dünyası'nı ziyaret "orta sınıf haccı, güneşte pişen kente zorunlu ziyaret" olarak tasvir edilmektedir. Aynı şekilde herhangi bir kentteki alışveriş merkezleri, insanların "tüketici inançlarını" yerine getirmek için gittikleri yerler olarak tarif edilmektedir. Ayrıca belirtilmelidir ki, tüketim katedralleri yalnızca büyülü ortamlar değildir. Aynı zamanda oldukça akılcılaştırılmıştır. Sürekli daha fazla tüketiciyi çekmek üzerine kurgulandıkları için, büyüleyicilikleri de sürekli yeniden üretilmiş olmalıdır. Günümüzün tüketim katedrallerinin en büyük sorunu da tam da buradadır. Asıl mesele, giderek artan akılcılık karşısında büyüleyiciliklerini nasıl koruyacakları konusudur (Ritzer 1, 2016:31-33). Ayrıca belirtmek gerekir ki, tüketimin ve bolluğun hâkim olduğu günümüzde kent ve sanayi ortamının etkisiyle yeni kıtlıklar ortaya çıkmıştır. Mekân ve zaman, temiz hava, temin su, yeşil bir ortam, sessizlik gibi şeyler artık kıt mallardır. Eskiden bedava olarak bol 
bol kullanılan bu mallar, sadece belli ayrıcalıklara sahip insanların ulaşabileceği lüks mallar haline gelmiştir. Bunun yanı sıra üretilen mal ve hizmetler bollukla tüketici kitlelere sunulmaktadır (Baudrillard, 2017:62).

Bilim ve teknoloji ile birlikte ekonomide yaşanan tüketim odaklı gelişmelerin kentlerin gelişmesine etkileri de önemlidir. Tüm bu gelişmelerin kentleşmeye pozitif yönde katkıları olduğu kadar olumsuz etkileri de olmuştur. Kentlerin yapısal değişiminden dolayı kentlileşen insanların hayat şekillerinde olumsuz anlamda değişmeler meydana gelmiştir. Dayanışma, akrabalık ilişkileri, hemşehrilik ilişkileri gibi özellikler yok olmaya başlamıştır. Artık kentler, yalnızlaşma ve yabancılaşmanın daha yoğun yaşandığı, insanların birbirlerinden ve çevrelerinden uzaklaştığı mekânlar halini almıştır. Modernleşen dünyada insanların doğduğu yerde büyümek, okumak, çalışmak, yaşamak gibi avantajları neredeyse ellerinden alınmış, sadece daha iyi yaşamak için bile sürekli mekân değiştirmek zorunda kalmışlardır. Bu durum da sürekli ve köklü insani ilişkileri zorlaştırmıştır. Bu tarz yeni kent ve kentlilik, insanlararası ilişkiler bakımından sadece statü olarak insanların önemsendiği, kişilik, akrabalık, arkadaşlık ilişkilerinin sınırlandırıldığı, hayatın bakmadan ya da görmeden yaşandığı mekânlar halini almıştır (Aydoğan, 2009:212).

Jean Baudrillard'a göre kapitalist sistem, eğer az gelişmeden, işsizlikten ve askeri harcamalardan beslenmeseydi, başka temeller üzerinde dengelenebilseydi ve kendi yaşamını böyle sürdürülebilseydi mutlaka bunu da yapardı. Kapitalizm yapısı gereği bugün gücünü "bolluk” sayesinde pekiştirebiliyorsa bunu yapmaktan kaçınmıyor. Özetle kapitalist sistem, "kendi varlı̆̆ını sürdürme koşullarını tanır, toplumsal ve bireysel içerikleri yadsır”. Tüketim, iletişim, kültür, bolluk, haber: tüm bunlar yeni üretici güçler olarak daha büyük kazanımlar için sistemin kendisi tarafindan gerçekleştirilmektedir. Dolayısıyla günümüzde kapitalist sistem bolluğu ve tüketimi, sömürü ve savaşın yerine geçirmiştir (Baudrillard, 2017:61-2). Tüketim toplumu daha fazla tüketebilmenin yaşamın amacı haline geldiği bir toplumdur. İnsan hayatının temel hedefi, geliştirdiği bilim ve teknolojiyi kullanarak doğayı denetim altına alıp mutluluğu yakalamaksa eğer, tüketim toplumu aslında hedefe ulaşmanın göstergesidir. Oysa durum tam olarak böyle olmamıştır. Modern dünyada sanayileşmeden daha hızlı gerçekleşen kentleşme, göçler nedeniyle kentleri kırsal değerlerin etkisi altında bırakmıştır. Tüketim toplumunun etkisiyle kırsal ve kentsel değerlerin sentezi, kentleri düzensiz hale getirmiştir. Bu durum, gelişmiş ülkelerdeki tüketim toplumunun mal ve hizmet tüketiminin aynısının gelişmekte olan ülkelerde de yayılmasına buradan da "marka bağımlılığı"nın doğmasına yol açmıştır (Aydoğan, 2009:213). Böylece toplumsal yaşama tüketim, marka, imaj, reklam, pazarlama gibi birçok kavram girdi. Tüketim, toplumu o kadar etkisi altına aldı ki, sadece giyecek ya da yiyecek gibi küçük şeylerde marka bağımlılığını geçti, insanların yaşadıkları kent dahil okudukları okullardan, alışveriş yaptıkları marketlere, tatil tercihlerine kadar her yere markalar hakim oldu.

Önceleri üretim mekanizmalarında metayı ürüne dönüştürmek mesele iken, bunu gerçekleştiren insan, bunun ardından ürünü imaja dönüştürme çabalarına girişti. Pazarlamanın sadece imajlar etrafında şekillendiği süreçler geçmişte kalırken, günümüzde değer yaratımı odaklı çalışmak önemli hale geldi. Değer yaratımı odaklı, deneyimlerin etkin olduğu "deneyim ekonomisi” gündemdedir. Deneyim ekonomisini yaratabilmek için kültürü tüketim odaklı hale getirmek gerekiyordu. Sistem bunu da gerçekleştirdi. Böylece tüketim kültürü kavramı insanların yaşamına hâkim oldu. Günümüzde üretim ile tüketimin yer değiştirdiği, tüketim olgusunun daha önemli hale geldiği görülmektedir (Bat1 3, 2018:31). Tüketim kültürünün hâkim olduğu kentlere en güzel örneğin Las Vegas olduğunu belirten Uğur Batı, "Deneyim ekonomisi konusunda Las Vegas örneği önemlidir. Kentin kendisi ideolojik bir metindir. Bugün tüketimcilik ve eşsiz deneyim kültürünün rahatlıkla gözlemlenebileceği eşsiz bir metin. Las Vegas'ta imajlar ile anlatılanlar arasında bir ilişki söz konusudur; imajlar sanki salt kendileriyle ilgiliymiş gibi görünür. Parlak neonlarla dolu, yapay bir imaj çeşitliliği söz konusudur. Las Vegas'ın egzotik kültür alanı, bir imaj zenginliği şeklinde kendini gösterir. Gerçekte Las Vegas'ın anlamsız, -içeriksiz olmak şöyle dursunkendine has bir ideolojisi, mesajlarl, değerleri olan bir yapı olarak görmenin ona öyle bakmanın mantıklı olacağı düşünülmektedir. Heyecan verici ve arzulara dayanan, tüketim kültürünü kapsayan, koca bir boş zaman etkinliği olarak görülen kent, tüketim ideolojisinin bir yansitıcısıdır. Dorukta bir heyecan duygusu, rekabetçi bir yaşam biçimi ve lüks tüketimi gösteren ikonik bir şehir görünmektedir. Kapitalist bir unsur olarak Las Vegas özgür girişim alanı olmasıyla onun temelini yansitır; kumar, uyuşturucu gibi sektörlerin özgürce kar sağlama alanı olan şehir, ultra kapitalist süreci örnekler. Bu bir bütün olarak yaşatılan ultra bir deneyimdir" demektedir (Batı 3, 2018:31-32).

\section{MARKA KAVRAMI VE MARKA KENTLER}

\subsection{Marka Kavramı:}

Pazarlama disiplinine ait bir kavram olan marka Türk Dil Kurumu Sözlüğünde, bir ticari malı ya da herhangi bir nesneyi tanıtmaya, benzerinden ayırmaya yarayan özel ad veya işaret olarak açıklanmaktadır. Markalaşma ise, tüketicilere yönelik olarak özgün, güvenilir ve sürdürülebilir bir algı yaratma sürecidir. Aslında markalaşmanın tek hedefi bilinirliktir. Ürün veya hizmet, tüketici ya da kullanıcı gözünde değer ve anlam kazandığında ve güven oluşturduğunda; tüketicinin veya kullanıcının beklentileri karşılık bulduğunda "marka" oluşumunu tamamlamış, artık bilinir bir "marka" olmuştur. Bir ürünün marka olması, marka adının kullanılması Sanayi Devrimine kadar 
uzanır. Markalaşma, 200 yıl kadar önce Josiah Wedgwood'un ürettiği porselenlere kendi adını basmasıyla başlamıştır. Özellikle İngiliz soylularının bu ürünlere ilgi göstermesiyle de, dünyanın ilk markası ortaya çıkmıştır (Alaş, 2009'dan alıntı yapan Kaypak, 2013:341). Burada belirtmek gerekir ki, bir şeyin marka olabilmesi için o şeye talep olmalıdır. Bunun içinde tüketimin olması gerekmektedir. Fakat Einstein'da birey olarak fizik alanında bir markadır. Dolayısıyla 21. yüzyılın küresel dünyasında herhangi bir şeyin marka olabilmesi için yalnızca üretilen alınıp satılan bir mal olması gerekmiyor. Bu bir birey de olabilir, bir ülke ya da bir kent te olabilir.

İlhan Tekeli markanın sahip olduğu nitelikleri şöyle sıralamıştır;

- Marka kavramı pazarlama bilim dalının geliştirdiği bir kavramdır.

- Marka kavramını mal ve hizmet üreticileri kullanmaktadır.

- Tüketicinin satın alma davranışları etkilenmeye ve yönlendirilmeye çalışılmaktadır.

- Her markanın o ürünün veya hizmetin sembolü haline getirilmiş, söz konusu ürünü diğerlerinden ayıran bir işareti vardır.

- Ticari marka, fikri ve sınai mülkiyet haklarının konusu olan ve bir isim, sözcük, logo, sembol, tasarım ya da tüm bunların karışımından oluşan simgedir.

- Herhangi bir şeyin marka haline gelmesi çok yönlü karmaşık bir olgudur. Ekonomik, sosyal ya da kültürel alanda rekabet şekilleri çerçevesinde oluşur, olgunlaşır ve ortaya çıkar.

- Marka olmak için tabii ki gerek bir üründe, gerek bir hizmet sunumunda düzenli bir çalışma veya başarı bulunması gerekir.

- Marka olmak söz konusu olduğunda, aslında hâlihazırda var olan ve devam ettirilmekte olan fakat bilinirliği olmayan bir başarının ortaya çıkarılarak o ürün veya hizmet hakkındaki farkındalığı artırmaktan bahsedilmektedir (Tekeli, 2018)².

Yine aynı makalede Tekeli, marka olmanın ürüne ya da hizmete getireceği avantajlardan bahsetmiştir. Öncelikle, söz konusu ürüne ya da hizmete talep arttığı için doğal olarak üreticisinin de karı artacaktır. Bu durum da müşteri sadakatini getirecektir. Özellikle günümüzün tüketim toplumunun ilgi gösterdiği "moda" akımlarının yarattı̆g dalgalanmalardan etkilenmeyecektir. Müşteri sadakatinden dolayı, üreticinin yeni üretimlerine veya hizmetlerine marka güvenilirliği nedeniyle, üreticinin yeni ürününü kabul ettirmesi çok daha kolay olacaktır. Burada belirtmek gerekir ki, markalaşmanın üreticiye olduğu kadar tüketiciye de sağladığı avantajlar vardır. Öncelikle, tükettiğgi ürüne dair güvencesi vardır ve riski azdır. Ayrıca bazı ürünleri satın almak, günümüzün tüketim toplumunda yaratılan algıya göre prestij satın almak olarak kabul edilmektedir (Tekeli, 2018).

İlişki üzerine kurulmuş sosyolojik kavramlar olan, paradoks, seçim, aidiyet, kimlik gibi olgular tam da markanın insan yaşamındaki yerini ifade etmektedir. Tüketicinin sadakatle markaya bağlanması için, markanın tüketici üzerinde tatmin ve güven duygusunu yaratıp, tüketicinin marka ile duygusal bağ kurmasının sağlanması gerekmektedir. Zaten duygusal bağ kuramayan marka ölü doğmuştur denilebilir. Öncelikle markanın tüketiciye daima "doğru seçimi" yaptığını hissettirmesi önemlidir. Marka ile gerekli duygusal bağ sağlandıysa, özellikle de marka ile yaşanan deneyim olumlu duygular bıraktıysa markaya aidiyet yaratılmış olur. Marka sadakati de böyle sağlanmaktadır. Marka sadakati, tüketicinin markaya olan inancının gücü olarak tanımlanabilir. Tüketicilerin bir markada belirli özellikler algılaması ve bu özelliklerden etkilenmesi o markaya duyulan sadakatin artmasına neden olmaktadır. Uğur Bat1, tüketici sadakatinin denklemini; "Tüketici Güveni + Tüketici Tatmini + Marka ile Kurulan Bă̆ = Sürdürülebilir Sadakat" olarak özetlemektedir. Sonuçta bütün markaların hedefinde, güçlü bir sadakatle markaya bağlı olan tüketici kitlesine sahip olmak vardır. Güçlü marka olmanın en temel özelliği sadık bir tüketici kitlesi yaratmasıdır denilebilir. Bunun içinde önce markanın "fark" edilmesi, sonra da "tercih" edilmesi gerekmektedir. Tercih edilme aşamasında tüketiciyi doğru seçimi yaptı̆ğına "ikna" etmek ve tüketiciye "güven" vermek önemlidir (Bat1 2, 2015:277-279).

Yaklaşık son 25 yıldır dünyayı etkisine alan küreselleşmenin ve bu sürecin etkisiyle gerçekleşen değişimin ekonomik güç üzerindeki etkileri de net bir şekilde görülmektedir. Özellikle markalaşmanın etkisiyle, tüketici gruplarının dikkatleri dünyanın bir ucundan diğer ucuna bile olsa çekilebilmektedir. Ayrıca dünyanın bugün geldiği durumda hiçbir şey izole bir ortamda gerçekleştirilememektedir. Özellikle de net bir şekilde görülen küreselleşmenin yarattığı tüketim toplumunda, karbon ayak izi ya da yerelde denizaşırı üretim gibi birçok şeyin iyi veya kötü yönleri tartışılmaktadır. Dolayısıyla tüketici davranışlarına göre üretim yapmak ve marka yaratmak da ticari anlamda bir tür zorunluluk haline gelmiştir (Bruce ve Harvey, 2010:29).

Marka olmak sürdürülmesi gereken, yönetilebilen bir süreçtir. Burada marka olacak ürünün güçlü ve zayıf yanlarının sürekli takibi ve analizi gerekmektedir. Markanın sürdürülebilir olması için üreticinin yenilikçi bir tavırla bu sürece yaklaşması önem arz etmektedir. Burada asıl önemli olan markanın piyasanın rekabet şartlarına dayanabilir olmasıdır. Ayrıca belirtmek gerekir ki, söz konusu ürünün marka olabilmesi, üretimden tanıtıma kadar

2 İlhan Tekeli’nin “Bir Kentin Kimliği Ve Marka Olması Konusunda Nasıl Düşünülebilir?” adlı makalesi Academia.edu internet adresinden alınmuştır.

154 | P a g e

www.iiste.org 
uzun, zorlu ve sürekli takip edilmesi gereken bir süreçtir. Sadece tanıtım ya da iletişime indirgenemeyen bir süreci kapsamaktadır (Tekeli, 2018).

Tüm bunların yanında tüketim toplumunun ve markalaşmanın belki de en akıldışı sonucu giderek artan homojenleşmedir. Günümüzde dünyanın neresine gidilirse gidilsin, sunumu aynı olan aynı ürünlerle karşılaşma olasıllı̆ 1 çok yüksektir (Ritzer 2, 2017:253). Küreselleşmeyi, "akışkanlı̆̆ın gittikçe arttı̆̆l, insanların, nesnelerin, mekânların ve bilginin her yöne aktığı; bunların karşısına çıkan ve yarattı̆̆ı yapıların bu akış önünde engelleyici veya hızlandırıcı bir rol oynadığl geçişken bir süreç veya süreçler dizisidir" ş̧eklinde tanımlayan George Ritzer aynılaşmanın bu süreçte olağan olduğunu ileri sürmektedir (Ritzer 2, 2017:325). Kaldı ki küreselleşme ve teknoloji ile birlikte benimsenen yaşam tarzında benzer işlevlere sahip farklı markalar ortaya çıktıkça eskinin lüks sayılan ürünleri artık her yerde görülmeye ve buna da "ihtiyaç" denilmeye başlanmıştır (Batı 2, 2015:77).

Sonuç olarak, gelenekselliğin, egzotikliğin ortadan kalktığı dünyanın her yerinde giderek aynı hayatlar yaşanmaya başlamıştır. Marka kent olmak ihtiyacı bu tarz aynılıklardan insanların kurtarılarak, farklılıklarla cazibe yaratılıp insanların etkilenmesi ve bir tür tüketime yönlendirilmesi şeklinde bir durum ortaya koymaktadır. Fakat burada ilginç olan markaların sıradanlaştırdığı ve aynılaştırdığı insan hayatının, yine marka olan kentlerle farklılaştırılmaya çalışılmasıdır.

\subsection{Marka Kentler:}

Küreselleşme sürecinde yaşanan ekonomik, teknolojik, siyasi, sosyo-kültürel gibi birçok alanda gerçekleşen dönüşümler bütünüyle kentlerde görülebilmektedir. 21. yüzyılda yaşanan tüm dönüşümlerin merkezi konumunda olan kentler, ulus devletin belirlediği çerçeveden çıkmaya çalışmaktadır. Dolayısıyla kentler, küresel sistemin hâkim olduğu dünyada toplumların ekonomik gelişmelerini belirleyen temel birimler haline gelmiştir (Keyder, 1996'dan alıntı yapan Kaypak, 2013:343). Aynı zamanda kentler, medeniyetlerin kurulduğu ve yaşadığı yerler olduğundan ekonomik olduğu kadar kültürel olarak da önem arz ermektedir. Çünkü kent uygarlık demektir ve her kentin kendi tarihi vardır. Birçok doğu dilinde ya da batı dilinde kent ve medeniyet aynı kökten gelmektedir. Bu da kentin medeniyetin temeli olduğunun göstergesidir (Kılıçbay, 2000:41).

Küreselleşme sürecine gelene kadar ulus devletin sınırları içinde yer alan kent, günümüzde dünya üzerinde kendi hinterlandını oluşturabilen ve bu nedenle de dünyadaki diğer kentlerle sürekli hem bir yarış halinde olup hem de süreci etkileyen ve süreçten de etkilenen bir sistem içinde yer almaktadır. Kentlerin ekonomik gelişmenin motoru olabilmeleri için küresel sermayeyi çekebilmeleri gerekmektedir. Bunun içinde altyapılarını tamamlamaları ve diğerlerinden fark yaratabilmeleri için çeşitli projeler geliştirmeleri gerek ve yeter şarttır (Kaypak, 2013:343). Bu konuda kentler arası rekabet önem kazanmaktadır. Ayrıca günümüzde hala tartı̧ılan başka bir konu vardır. Özünde "gelenekçiliğin" "moderniteye" yenilmesi konusu değildir. İlerici bir şehircilik anlayışı karşısında "kültüralist" ya da "nostaljik" bakış açısı da değildir. Kent farklılıkların mekanı olduğundan, tartışmanın özünde kentleri konu olan tüm bu hareketlerin gerekliliği konusudur (Bumin, 2010:2). Küreselleşmenin gereklerini karşılayabilen, kendilerini yenileyebilen, sanayi kentlerinin ağırlığını üzerinden atabilen, küresel refahtan payını alabilmektedir. Dolayısıyla tüm gerekleri yerine getirip küresel sisteme uyumlanmayı başarabilen kentler ön plana çıkarken, bunları karşılayamayan kentler de önemini kaybetmektedir. Küresel sermayeden payını alabilen ve iş yaratarak, üretim yaparak bu sermayeyi kontrol edebilen, hem sosyo-kültürel alanda hem de turizm de dikkatleri çeken kentler "küresel kent" olarak adlandırılmaktadır. Dünyada ayrıcalıklı olarak görülen bu kentlere "dünya kenti” de denilmektedir. New York, Londra, Tokyo, Paris gibi 20-25 kent, dünya kenti ya da küresel kent olarak tanınmaktadır (Kaypak, 2013:344). Bu kentler sınırları içinde bulundukları devletlerin her açıdan önüne geçmiştir. Marka olmak için bir çaba göstermeleri de gerekmemektedir. Hâlihazırda küresel sermayeden de önemli oranda pay alabilmektedirler.

Küreselleşme kentlere rekabet olarak yansımıştır. Rekabetin, kentlerle yerel düzeye kadar inmesi küresel sistemde bir tür hayatta kalma mücadelesine dönüşmüştür. Dolayısıyla kentlerin bu duruma farkındalık geliştirerek, diğer kentlerle yarışabilmek için çeşitli çalışmalar yapmaları zaruri hale gelmiştir. Son yıllarda çok sık dile getirilen "marka kentler" ya da "kentlerin markalaşması" bu farkındalığın gelişmesinin sonucu ortaya atılmış kavramlardır. Kent markası, "bir kentin sahip olduğ u kültürel, tarihsel, doğal ve toplumsal özellikleriyle bütünleştirerek ve diğer kentlerden ayırt etmek amacıyla kendine özgü bir işaretle destekleyerek yaşama geçirdiği bir gelişim-tanınmaimaj projesidir" şeklinde tanımlanmaktadır. Kent marka imajı ise, "kitlelerin kent ismini duyduklarında ne düşündüklerinin toplamını" ifade eden kavramdır (Kaypak, 2013:345).

Markalaşma herhangi bir ürün için, olası tüketicilerine, onların kim oldukları ya da kim olabilecekleri konusunda, nasıl bir hayat istedikleri ve nasıl bir durumun içinde bulunmak istedikleri konusunda deneyimler yaratır. Temeli hazcıllığa dayanan bugünün tüketici davranışları, arzunun dışa vurumu ve ayırt edici göstergeler üzerinden kültürel değerler bütününün üretilmesidir. Zaten günümüzün yaşam tarzının temel vaadinin haz almak, mutlu etmek, sevmek, övmek, acı duymak gibi temel duygular üzerine kurulu olduğu söylenebilir (Batı 3, 2018:102). Burada bir ürünün markalaşması için bahsedilen her şey kentler içinde geçerlidir. Özellikle deneyim yaratmak çok önemlidir. 
Kentler ekonomik, sosyo-kültürel, siyasal olmak üzere birçok bileşenin birlikte yer aldığı yerleşmelerdir. Kentte bulunan mekânlar, kentin tarihi ve doğal çevresi, kentin ekonomisinin bağlı olduğu mekânlar, kentin kültürel yapısı gibi birçok faktörden oluşan kent kimliği, uzun zaman dilimlerinde ş̧ekillenir. Coğrafi özellikler, gelenekler, mimari yapı gibi birçok özellik de kent kimliğinin temelini oluşturur (Kaypak, 2013:345). Kentin kimliği, imgelenebilirliğine bağlıdır. İmgelenebilirlik kavramının düzenli, sınırlı, kesin, tektipleştirme gibi anlamları içermesi gerekmez. Örneğin güzel bir kentin çevresinin imgelenmesi farklı özellikleri de taşır: anlam ve dokunaklılık, duyusal hazlar, ritim, uyaranlar, seçenekler. Burada amaç sadece algısal dünyada kimlik ve yapıya olan ihtiyacı ortaya koymak ve tüm bunların değişken olan kentsel çevre ile ilgili karmaşık ilişkisini anlaşllır kılmaktır (Lynch, 2011:11).

Markalar bir şekilde, çok boyutlu ilişkiler ile bir "anlamlar dünyası" yaratarak tüketicilerin kimliklerini belirleme, toplumla bütünleşme sağlama, bireysel farklılıklarını vurgulama işlevlerini gerçekleştirir. Marka olmak, daha cazip ya da daha çekici olmak anlamına gelmektedir. Marka olmak en az bir özelliği ile ön plana çıkarak farklılaşmayı gerektirir. Her büyük kent marka kent değildir. Bir kent coğrafi avantajını kullanarak, kentsel yenilemesini sağlamış, ekonomisini kendi kaynaklarıyla büyütmüş, düzenli bir nüfusa sahip, sosyo-kültürel hayatını düzenlemiş olabilir. Fakat düzenli bir turizm potansiyeli yoksa en az bir özelliğiyle ön plana çıkmıyorsa, ya da dışarıdan yatırımcı çekemiyorsa o kent marka kent değildir. Ayrıca her kentin marka kent olmak gibi bir zorunluluğu da yoktur (Kaypak, 2013:345). Aslında kentlerin marka haline gelebilmesi biraz da coğrafi konumundan kaynaklanan avantajlara bağlıdır. Özellikle ekonomik anlamda gerek yurtiçi gerekse yurtdış1 bağlantılı yatırımcıları, turistleri, ticari faaliyetleri kendine çekebilen kentler, diğerlerine göre marka olmakla ilgili çalışmalarda ön plandadırlar. Marka kent olmaktaki amaç, kentin cazibesini artırarak gelen ziyaretçilerin sayısını artırmanın yanında, kente yapılan yatırımları artırmaktır. Dolayısıyla kentlerin ekonomik kalkınmalarını sağlayarak, kentteki yaşam kalitesini artırmak ve orada yaşama fikrini insanların zihnine yerleştirmektir. Ayrıca sosyal dışlanmayı engelleyerek herkesin sahiplenebileceği bir yerel kimlik oluşturmak ve kentte yaşayan toplumun gelişmesini sağlamak da marka olmanın amaçları arasında yer almaktadır (Alaş, 2009: II).

Marka olmak isteyen bir kentin, ilk etapta kendisini cazip hale getirebilecek özelliklerinin tespit edilmesi gerekmektedir. Kentlerin cazibelerini artıran faktörler iki grupta incelenmektedir. Birinci grupta, ekonomi, iletişim altyapısı, stratejik konumu, mülkiyet durumları, yerel destek hizmetleri ve teşvikler yer almaktadır. İkinci grup da, yaşam kalitesi, işgücü, rekabet durumu, kişisel faktörler, yönetim, profesyonellik düzeyi, girişimcilik ortamı gibi faktörleri içermektedir (Aladağ, 2009:3). Ayrıca belirtmek gerekir ki, kentin gelişim planlarını tamamlamak, kentsel dönüşümü tamamlamak ya da altyapı yatırımlarını tamamlamak marka olmak için yeterli değildir. Bir kentin diğerleri ile rekabet etmek gereğini hissetmesi marka kent olmanın ilk aşamasıdır. Rekabet etmek için gereğini yapma çalışmalarına başlamak ikinci ve bu çalışmaların sürekliliğini sağlamak da üçüncü aşamasıdır (Kaypak, 2013:348). Dolayısıyla marka olmak uzun bir süreçtir. Herhangi bir ürünün ya da hizmetin marka olmas1 için izlenen yol yaklaşık olarak kent için de aynıdır: Tanıtım, iyi hizmet, yüksek kalite ve güven. Marka kent olmak da, strateji, yöntem ve tekniklerin kentler için uygulanması anlamına gelmektedir ve güven kavramı çok önemlidir. Marka olan kent, yatırımcılara güven vermek zorundadır (Alaş, 2009: I). Güvenin devamlılı̆̆ da büyük önem arz etmektedir.

Markalaşmak cazip olmak, emsalleri arasında tercih edilen olmaktır. Bunun için de bir strateji belirlenmesi gerekmektedir. Burada talep istikrarını sağlamak önemlidir. Ancak kentler bir ürün değildir ve sadece bir iletişim stratejisi ile marka yaratılamaz. Kent markalaşması için çok yönlü bir strateji geliştirilmesi gerekmektedir (Tekeli, 2018). Vizyon, bir tür gelecek öngörüsü, sonunda erişilmesi istenen hedef olarak açıklanabilir. Fakat o hedefinde gelecekte kurulan hayaller değil, gerçek koşullar çerçevesinde ele alınması gerekir. Denize sahili olmayan kente doğal olarak gemi sanayi düşünülemez (Kaypak, 2013:349). Vizyon, markalaşmanın temel taşıdır. Vizyonu yanlış belirlenen bir kent, marka olamayacak, gösterilen gayretler boşa gidecek, yapılan çalışmalar zaman ve para kaybından öteye geçemeyecektir. Marka kent olmak, kentin dünyada tanınmasıyla olur. Zaten küreselleşme nedeniyle herhangi bir yerde doğan bir birey rahatllkla başka bir yerde yaşar ve çalışır hale gelmiştir. Aslında marka, kentin tamamını kapsayan bir kimlik yaratma sürecidir. Kentin markalaşması için katılımcı bir süreç takip edilmelidir. Bir kentin markalaşma süreci, kentte yaşayan insanlar ve kentin yöneticileri, kurum ve kuruluşlar, iş dünyası, sivil toplum örgütleri gibi ne kadar geniş katılımla yürütülürse o kadar iyi olur. Çünkü yaratılan kent kimliğini kentte yaşayan herkesin benimsemesi gerekmektedir. Marka, kentin özgün kimliğini yansıtmalıdır. Kentin kimliğinde herhangi bir belirsizlik olursa, söz konusu kenti hatırlatmıyorsa markalaşma başarısızdır (Tekeli, 2018).

Sonuç olarak marka kent, hedeflenen ne ise onu karşılayacak şekilde kentin kendisine çekidüzen vermesidir. Kentte yaşayanlar ve kentteki iş dünyası kentte yaşamaktan mutlu olduysa, yatırımcılar ile kente gelen ziyaretçiler kentte bulunmaktan memnunsa ve beklentiler karşılandıysa o kentte markalaşma başarılmış kabul edilir (İlgüner ve Asplund, 2011:220). 


\section{SONUÇ VE TARTIŞMA}

Kentler, medeniyetlerin kurulduğu ve yaşadığı yerler olarak insan yaşamı açısından çok önemlidir. Uygarlık tarihi aynı zamanda kent tarihi olarak anıldığ 1 için, toplumların geçmişten günümüze geçirdiği değişim ve dönüşümlere göre kentler de değişip dönüşmüştür. Günümüz toplumunun en belirgin özelliği olan tüketim kültürü kentleri de doğal olarak etkilemiş dönüşüme uğratmıştır. Bilim ve teknolojinin çok hızlı ilerlemesi bu dönüşümleri hem hızlandırmış hem de yaygınlaştırmıştır. Özellikle bireylerin hayatını kolaylaştıran iletişim ve ulaşım teknolojileri, bilgiye erişimin kolaylaşması gibi birçok nedenle toplumlar aynılaşmaya başlamış, beklentiler yükselmiştir. Bu durum doğal olarak kentlere de yansımıştır. Öncelikle kentte yaşayanların beklentilerini karşılama oranına göre kentlere değer biçilir hale gelmiştir.

Küreselleşmenin getirdiği aynılaşma ve rekabet ortamından etkilenmeyen devlet ve kent kalmamıştır. Özellikle söz konusu olan küresel sermaye olduğu için bu konu devletler için çok önemlidir. Kaldı ki kentler de artık bağlı bulundukları devletten bağımsız ön plana çıkarak küresel sermayeden pay alabilmektedirler. Dünyanın 20-25 kenti dünya kenti olarak adlandırılır ve herhangi bir ilave çabaya gerek olmadan zaten tercih edilir durumdadırlar. Oysa diğer kentlerin bilinirlik için çaba göstermeleri gerekmektedir. Bu kentler de coğrafi konumlarını, tarihlerini, doğal güzelliklerini ya da yatırım olanakları gibi bir takım ayrıcalıklı durumlarını kullanarak kendilerini cazibe merkezi haline getirmenin yollarını aramaktadırlar. Bu yollardan en bilineni marka olmak olduğu için genel anlamda tercih edilmektedir. Bir kent için marka olmak, tıpkı bir ürünün markalaşma sürecinde olduğu gibi ilerlemektedir. Ancak kent, bir ürün olmadığı için ilaveten çeşitli tecrübelerden edinilmiş deneyimlerden de yararlanılmaktadır.

Tüketim kültürünün hâkim olduğu günümüzde insanların haz alma duygularını ne karşılıyorsa ona yönelmeleri aynılaşmayı getirmiştir. Aynı zamanda bu aynılaşma bireyleri değişim arayışlarına yönlendirmektedir. Tüketimden haz alma yükseldikçe aynılaşma yükselmekte ve değişim ihtiyacı daha da artmaktadır. Ürünler konusunda yaşanan bu çelişkili ama doğru orantılı markalaşma sonucunda bireyler marka sadakatini unutup arayışa girmektedirler. Tüm bu çelişkilere rağmen kentler de bilinirliklerini sağlamak için markalaşma yoluna gitmektedirler. Örneğin birkaç markanın fast food restoranlarını ya da kafeleri dünyanın neredeyse her yerinde bulunabiliyor. Dolayısıyla bunların bir kentte bulunması bir ayrıcalık değil sıradan bir durum haline geliyor. Kapitalizm tüketim toplumunun sürekli tüketmesini beklediği için markaların doğduğu dünyada yaşanan aynılaşmanın verdiği sıradanlık, kentlerde markalaşma ile aşılmak isteniyor. Üstelik markalaşmanın başarılı olduğu kent, tüketici toplumun hazcı davranışından dolayı sürekli yenilik yaparak, ilgiyi aktif tutmak zorundadır. $\mathrm{Bu}$ konuda deneyim yaşatarak marka sadakati sağlamak ürünlerde bir oranda işe yarasa da, kentlerde bu durum daha farklı olabiliyor. Mesela turizmde tercih edilen bir yer kendini sürekli yenilemezse en fazla birkaç yıl sonra cazibesini kaybediyor. Tüketim toplumunun hazcı yapısı marka sadakatinin önüne geçebiliyor.

$\mathrm{Bu}$ çalışmada incelenen tüketim toplumu kavramı ortada yokken Dostoyevski "Yeraltından Notlar" adlı eserinde “...önüne dünya nimetlerinin hepsini serseniz, başı kaybolana, hatta su yüzüne ufak ufak kabarcıklar çıkana kadar saadet deryasına gömseniz, çalışmaya ihtiyacı olmayacak derecede refahını sağlasanız da, sırf ballı çörekler yiyip yan gelip yatması, bir de insan neslinin kurumaması için iktisadi refaha kavuştursanı da... İnsanoğlundan ne beklenilebilir?" (Dostoyevski, 2017:32) cümleleriyle yaklaşık olarak yüz küsur yıl önce bahsettiği insan doğasının aynısının günümüzde de görülmesi gelecek açısından da düşündürücüdür.

Aynı zamanda Geoffrey Miller'ın tüketim toplumuna yaklaşımını ifade ettiği, “...zaman makinesiyle 30 bin yıl geriye gidin, Cro-Magnonlarla ${ }^{3}$ buluşun. Onlara modern sistemimiz olan tüketim kapitalizmini anlatın ve ne düşündüklerini anlamaya çalışın. Her zamankinden daha iyi şekilde refah, boş zamana sahip ve bilgili manzaramız olan tarım, hayvancılık, sur içi şehirler, para, sosyal sınıflar ve gösterişçi tüketimi keşfetmeye motive edebilecek misiniz acaba? Yada yontma taş ve mağara resim sanatlartyla kendi kültürlerinden ileri gitmemeyi mi tercih edecekler?... ”(Miller, 2012:9) cümleleriyle günümüz toplumunun içine düştüğü çelişkilere dikkat çekmektedir. $\mathrm{Bu}$ soruların cevabı verilemez ama günümüz insanının kendi yarattığı kalıpların içinde özgürlüğünü kaybettiği düşünülebilir.

Özetle belirtmek gerekirse, günümüzde bilim ve teknolojinin ve markaların sıradanlaştırdığı insan yaşamı, yine "marka" olan kentlerle ilginç hale getirilmeye çalışılmaktadır. Tüketim toplumu ile karakterize edilen içinde bulunduğumuz çağda tüm bu ilginçleştirme çabalarının nasıl sonuç vereceği bilinmemektedir. Marka olan kentlerin tüketim toplumunun arayışlarına ne cevap vereceğini gelecek mutlaka gösterecektir.

\footnotetext{
${ }^{3}$ Dünyada bilinen ilk modern insanlardir. Kalıntılarl 35 bin yll öncesine dayanmaktadır

157 | P a g e

www.iiste.org
} 


\section{KAYNAKÇA}

ALADAĞ, Ömer Faruk (2009), Kent Pazarlaması ve Marka Kentlerin Geliştirilmesinde Başarıyı Etkileyen Faktörler, Firat Kalkınma Ajans1, Internet Sitesi: http://fka.gov.tr/sharepoint/userfiles/Icerik_Dosya_Ekleri/FIRAT_AKADEMI/\%20\%20KENT\%20PAZA RLAMASI\%20VE\%20MARKA\%20KENTLER\%C4\%B0N\%20GEL\%C4\%B0\%C5\%9ET\%C4\%B0R\% C4\%B0LMES\%C4\%B0NDE\%20BA\%C5\%9EARIYI\%20ETK\%C4\%B0LEYEN\%20FAKT\%C3\%96RL ER.pdf, Erişim Tarihi: 29.09.2018.

ALAȘ, Betül (2009), Marka Kent Olmak - I, İnternet Adresi: http://www.izto.org.tr/portals/0/pusuladergisi/2009/05-06/5.pdf, Erişim Tarihi: 28.09.2018.

ALAŞ, Betül (2009), Marka Kent Olmak - II, İnternet Adresi: http://www.izto.org.tr/portals/0/pusuladergisi/2009/07-08/4.pdf, Erişim Tarihi: 28.09.2018.

AYDOĞAN, Filiz (2009), Tüketim Kültürünün Gölgesinde Kentler, Marmara Üniversitesi İ.İ.B.F. Dergisi, Cilt: XXVII. Sayı: II, Syf. $203-215$.

BATI 1, Uğur (2015), Tüketici Davranışları, ALFA Basım Yayım Dağıtım, İstanbul.

BATI 2, Uğur (2015), Marka Yönetimi, ALFA Basım Yayım Dağıtım, İstanbul.

BATI 3, Uğur (2018), Markethınk Ya Da Farkethınk, Destek Yayınları, İstanbul.

BAUDRİLLARD, Jean (2017), Tüketim Toplumu, çev. Nilgün Tutal \& Ferda Keskin, Ayrıntı Yayınları, 10. Basım, İstanbul.

BRUCE, Duncan ve David HARVEY (2010), Marka Bilmecesi, çev. Aslı Özer, İş Bankası Kültür Yayınları, İstanbul.

BUMIN, Kürşat (2010), Demokrasi Arayışında Kent, Çizgi Kitabevi, 4. Baskı, Konya.

DOSTOYEVSKİ, Fyodor Mihayloviç (2017), Yeraltından Notlar, çev. Nihal Yalaza Taluy, Türkiye İş Bankası Kültür Yayınları, 19. Basım, İstanbul.

HABERMAS, Jurgen (2002), Küreselleşme ve Milli Devletlerin Akıbeti, çev. Medeni Beyaztaş, Bakış Yayınları Düşünce Dizisi, İstanbul.

HABERMAS, Jurgen (2004). “İdeoloji” Olarak Teknik ve Bilim, çev. Mustafa Tüzel, Yapı Kredi Yayınları, İstanbul.

İLGÜNER, Muhterem ve Christer ASPLUND (2011), Marka Şehir, Markating Yayınları, İstanbul.

JHALLY, Shut (2002), Kıyametin Sinırında Reklamcılık, çev. Filiz Aydoğan, Birikim Dergisi, Sayı: 159, Syf. 77-86.

KAYPAK, Şafak (2013), Küreselleşme Sürecinde Kentlerin Markalaşması ve “MARKA KENTLER”, C.Ü. İktisadi ve İdari Bilimler Dergisi, Cilt 14, Sayı 1.

KELEŞ, Ruşen (1998), Kentbilim Terimleri Sözlüğü, İmge Kitabevi Yayınları, Ankara.

KILIÇBAY, Mehmet Ali (2000), Şehirler ve Kentler, İmge Kitabevi, İstanbul.

KUTLU, Erol (2000), Bilgi Toplumunda Kalkınma Stratejileri, Anadolu Üniversitesi Yayınları, No:1209, Eskişehir.

LYNCH, Kevin (2011), Kent İmgesi, İrem Başaran, Türkiye İş Bankası Kültür Yayınları, 3.Baskı, İstanbul. 
MAYOR, Frederico, Augusto FORTI (eds.) (2004), Bilim ve İktidar, çev. Mehmet Küçük, TÜBITTAK Popüler Bilim Kitapları 48, Ankara.

MCCLELLAN III, James E., Harold DORN (2006), Dünya Tarihinde Bilim ve Teknoloji, çev. Haydar Yalçın, Arkadaş Yayınevi, Ankara.

MILLER, Geoffrey (2012), Tüketimin Evrimi, çev. Gülçin Vardar, ALFA Basım Yayım Dağıtım, İstanbul.

RITZER 1, George (2016), Büyüsü Bozulmuş Dünyayı Büyülemek, çev. Funda Payzın, Ayrıntı Yayınları, 3. Basım, İstanbul.

RITZER 2, George (2017), Toplumun McDonaldlaştırılması, çev. Akın Emre Pilgir, Ayrıntı Yayınları, 5. Basım, İstanbul.

SAÇLI, Ahsen (2009), Uluslararası Çevre Politikaları Çerçevesinde Çevre-Teknoloji İlişkisi, Yayınlanmamış Doktora Tezi, Ankara.

SANDER, Oral (2005), Siyasi Tarih İlkçağlardan 1918'e, I. Cilt, İmge Kitabevi, Ankara.

ÜNDER, Hasan (1996), Çevre Felsefesi, Doruk Yayıncılık, Ankara.

TEKELİ, İlhan (2018), Bir Kentin Kimliği Ve Marka Olması Konusunda Nasıl Düşünülebilir?, İnternet Adresi: https://www.academia.edu/29393180/B\%C4\%B0R KENT\%C4\%B0N_K\%C4\%B0ML\%C4\%B0\%C4\%9 E\%C4\%B0_VE_MARKA_OLMASI_KONUSUNDA_NASIL_D\%C3\%9C\%C5\%9E\%C3\%9CN\%C3\%9 CLEB\%C4\%B0L\%C4\%B0R?auto=download, Erişim Tarihi: 1209.2018. 